\title{
Corrosion and Passivation Behaviours of Iron in Molten
}

\author{
Alkali Carbonates \\ S.S. Mahmoud * \\ Chemistry Department, University College of Girls for Arts, Science and Education, Ain Shams \\ University, Heliopolis, Cairo, Egypt
}

Received 6 October 2004; accepted in revised form 20 September 2005

\begin{abstract}
The corrosion and passivation behaviours of iron in ternary molten $\mathrm{Li}_{2} \mathrm{CO}_{3}-\mathrm{Na}_{2} \mathrm{CO}_{3}$ $\mathrm{K}_{2} \mathrm{CO}_{3}$ mixture at different temperatures $\left(475-550{ }^{\circ} \mathrm{C}\right)$ were studied. The techniques of measurements were: open- circuit potential, galvanostatic anodic polarization, and cyclic voltammetry. The amounts of iron dissolved in the melt were determined by atomic absorption spectroscopy after each experiment. Iron undergoes spontaneous passivation upon its immersion in the melt and the thickness of the oxide scales increases with the increase of temperature. During the passivation potential range different oxides and spinals are formed. These include a cubic solid solution of $\mathrm{FeO}$ and $\alpha-\mathrm{LiFeO}_{2}, \alpha-\mathrm{LiFe}_{5} \mathrm{O}_{8}$ and $\alpha-\mathrm{Fe}_{2} \mathrm{O}_{3}$. At high anodic potentials the decomposition of carbonate takes place leading to passivity break down and $\mathrm{CO}_{2}$ and $\mathrm{O}_{2}$ gases evolution. Also, the spoliation of oxide scales in the carbonate melt occurs at the passivity breakdown. The values of corrosion parameters $\left(\mathrm{R}_{\mathrm{p}}, \mathrm{i}_{\mathrm{o}}, \mathrm{i}_{\mathrm{corr}}, \mathrm{i}_{\mathrm{p}}\right)$ were calculated. The different values of activation energy of corrosion process were calculated. The results of cyclic voltammetric investigation indicate the formation of different oxides and spinals, and the cathodic and anodic decomposition of carbonate. The corrosion tests in $0.05 \mathrm{M}$ $\mathrm{HCl}$ solution indicate that the oxide scales formed on iron are multilayered. The outer layer is less protective than the inner one.
\end{abstract}

Keywords: molten alkali carbonate, corrosion, passivation, iron.

\section{Introduction}

Fused salts are considered now as an accepted medium in many industrial processes: they have been applied as coolants in nuclear reactors, heat transfer processes and as reaction media in chemical and electrochemical processes. They meet the requirements of many energy conversion processes, especially in fuel cell applications [1-5].

Molten alkali carbonates have drawn the attention of many research groups because their useful applications in environmentally safe fuel cells [5-8] and the

\footnotetext{
*Corresponding author. E-mail address: drsohairr@hotmail.com
} 
recent developments, including fuel recovery such as hydrogen methane and other hydrocarbons from natural bio-compounds.

Material degradation as a result of corrosion reactions is an important issue in energy production and energy consumption devices, especially current collectors and other metallic components of fuel cells $[2-4,9,10]$. Reactions between alloys and metals and carbonate are technologically important in view of long term stability of molten carbonate fuel cells, which are under continuous development. Particular interest was paid to the corrosion processes occurring at the current collectors and steel parts of the fuel cell construction.

The corrosion behaviour of stainless steel in molten alkali carbonate was the subject of many investigations [2,5,10-12]. The ternary alkali mixture $\mathrm{Li}_{2} \mathrm{CO}_{3}$ $\mathrm{Na}_{2} \mathrm{CO}_{3}-\mathrm{K}_{2} \mathrm{CO}_{3}$ represents a promising mixture because of its relatively low melting point $\left(397{ }^{\circ} \mathrm{C}\right)$ and good electrical characteristics [1,2]. Iron can be considered as the main component in the stainless steel. For this reason, in the present investigation, the corrosion and passivation behaviours of iron in such ternary molten alkali carbonate mixture were studied. In this respect, opencircuit potential, galvanostatic anodic polarization and cyclic voltammetry measurements have been employed.

\section{Experimental}

Iron samples were supplied from iron and steel company, Egypt. The ternary molten mixture of pure lithium carbonate $\left(\mathrm{Li}_{2} \mathrm{CO}_{3}\right)$, sodium carbonate $\left(\mathrm{Na}_{2} \mathrm{CO}_{3}\right)$ and potassium carbonate $\left(\mathrm{K}_{2} \mathrm{CO}_{3}\right)$ has a molar ratio of 43.5: 31.5: $25.0 \mathrm{~mol} \%$, respectively.

The carbonate mixture was placed in a Pyrex glass tube in an electrically heated furnace where it was melted at $450{ }^{\circ} \mathrm{C}$. The traces of humidity in the mixture were removed by bubbling pure dry $\mathrm{CO}_{2}$ gas in the melt for 2 hours. The mixture was left to cool in a dry atmosphere and the solidified mass was crushed and kept in a closed desiccator ready for use. In each experiment $50.0 \mathrm{~g}$ of the prepared ternary mixture were used.

The electrochemical cell consists of a Pyrex glass tube of $100 \mathrm{~mL}$ capacity in which the melt and electrodes were placed. The whole tall tube was placed in an outer cylindrical closed end alumna crucible of $500 \mathrm{~mL}$ capacity. The system was rendered gas tight using an O-ring seal between the outer alumna crucible and a stainless header in which the electrodes were fixed. The whole system was heated to the experimental temperature in an electrically heated vertical tube furnace. A Ni/Ni-Cr thermocouple, which was contained in a special tube to separate it from the melt, and a temperature indicator have been used for the temperature control.

The iron working electrodes were cut from iron samples, as sheets of $1 \mathrm{x} 1 \mathrm{~cm}^{2}$ area and $0.1 \mathrm{~cm}$ thickness. Each electrode was provided with a side $20 \mathrm{~cm}$ long and $0.2 \mathrm{~cm}$ width arm of the same material covered with a Pyrex glass tube of suitable diameter. The Pyrex tube was fused at the lower end directly attached to the square working area and sealed at its upper end by a suitable epoxy leaving an electrical contact. 
Before each experiment, the electrode was abraded by energy papers of different grades down to $4 / 0$, degreased with acetone and then immersed quickly in the melt. In each experiment a new iron electrode was used.

The potential of the working electrode was measured against a $\mathrm{Ag} / \mathrm{AgCl} / \mathrm{Cl}^{-}$ electrode which was accepted as a suitable reference electrode for such media $[7,8,13]$ by means of a D.C. microvoltmeter. A platinum sheet of dimensions $1 \times 1$ $\mathrm{cm}$ was used as an auxiliary electrode. The constant current was obtained from a DC power supply (LG Precision Co, Ltd, Korea). The cyclic voltammetric measurements have been performed using the 1M5D (Zahnes Elektrik GmbH) impedance system. The amounts of iron dissolved in the melt after experiments were determined by atomic absorption spectroscopy using flame-atomic absorption spectrophotometer Perkin- Elmer Apparatus model 23, (Germany). In the corrosion tests of oxide scales in $0.05 \mathrm{M} \mathrm{HCl}$ the potential is measured relatively to saturated calomel electrode (SCE) as a reference.
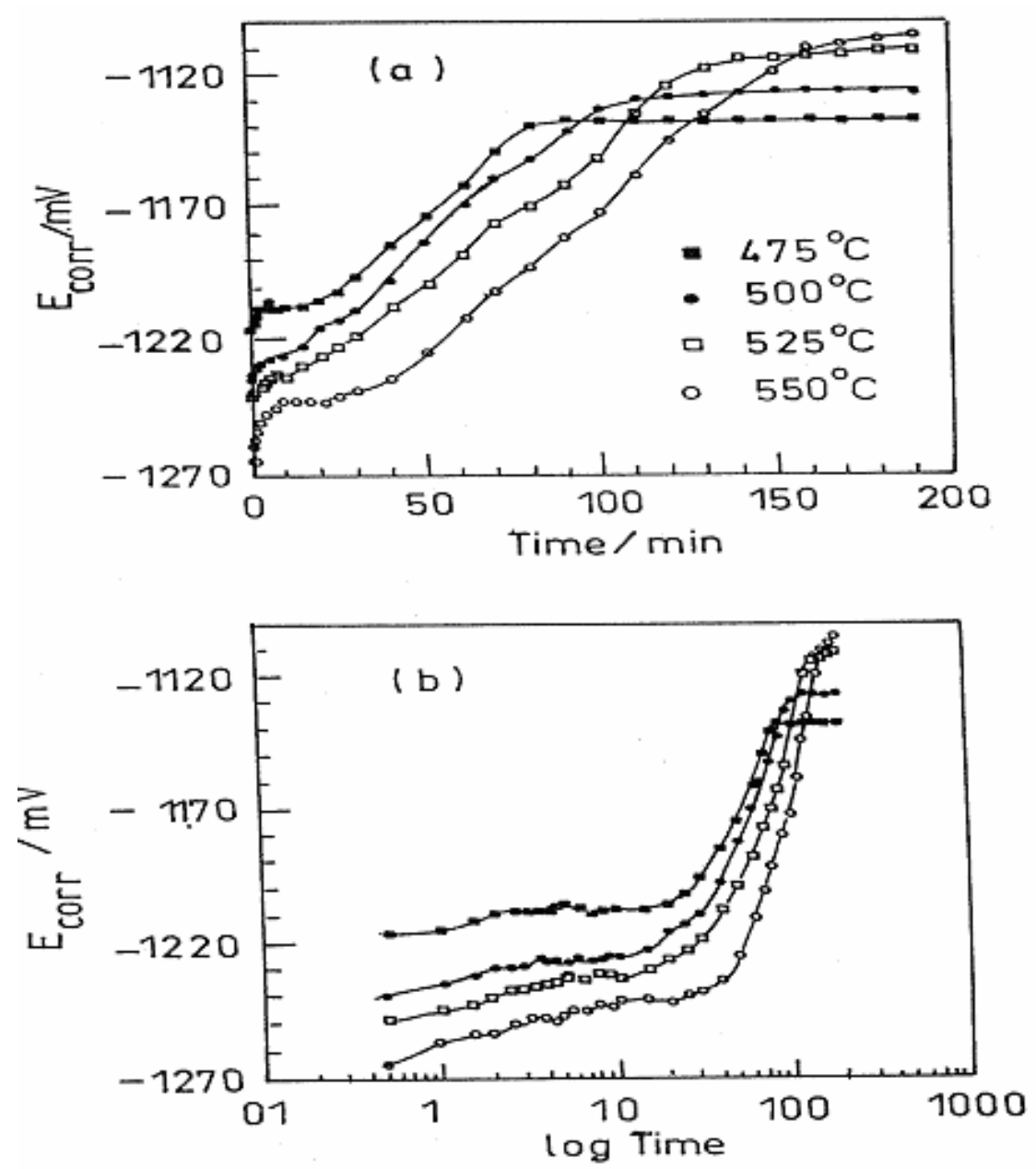

Figure 1. Variation of corrosion potential of iron with (a) time, (b) log time in carbonate melts at different temperatures. 


\section{Results and discussion}

Fig. 1a and $1 \mathrm{~b}$ represent, respectively, the plots of $\mathrm{E}_{\text {corr }}$ versus time $(\mathrm{t})$ and $\mathrm{E}_{\text {corr }}$ versus $\log \mathrm{t}$ for iron electrode immersed in molten $\mathrm{Li}_{2} \mathrm{CO}_{3}-\mathrm{Na}_{2} \mathrm{CO}_{3}-\mathrm{K}_{2} \mathrm{CO}_{3}$ mixture at different temperatures of $475,500,525,550{ }^{\circ} \mathrm{C}$. It is clear from the curves of Fig. 1a that upon immersion of the electrode in the melt, the corrosion potential shifts to the more positive direction with elapse of time till attaining the steady-state within 90-190 minutes from the moment of its immersion. The higher the temperature the larger the time required, $t_{s}$, to reach the steady-state. From the plot of Fig. 1b, $\mathrm{E}_{\text {corr }}$ vs. $\log \mathrm{t}$, it can be shown that before attaining the steady state potential each curve contains two different slopes $K_{2}$ and $K_{3}$. The calculated values of $K_{3}$ are higher than those of $K_{2}$.
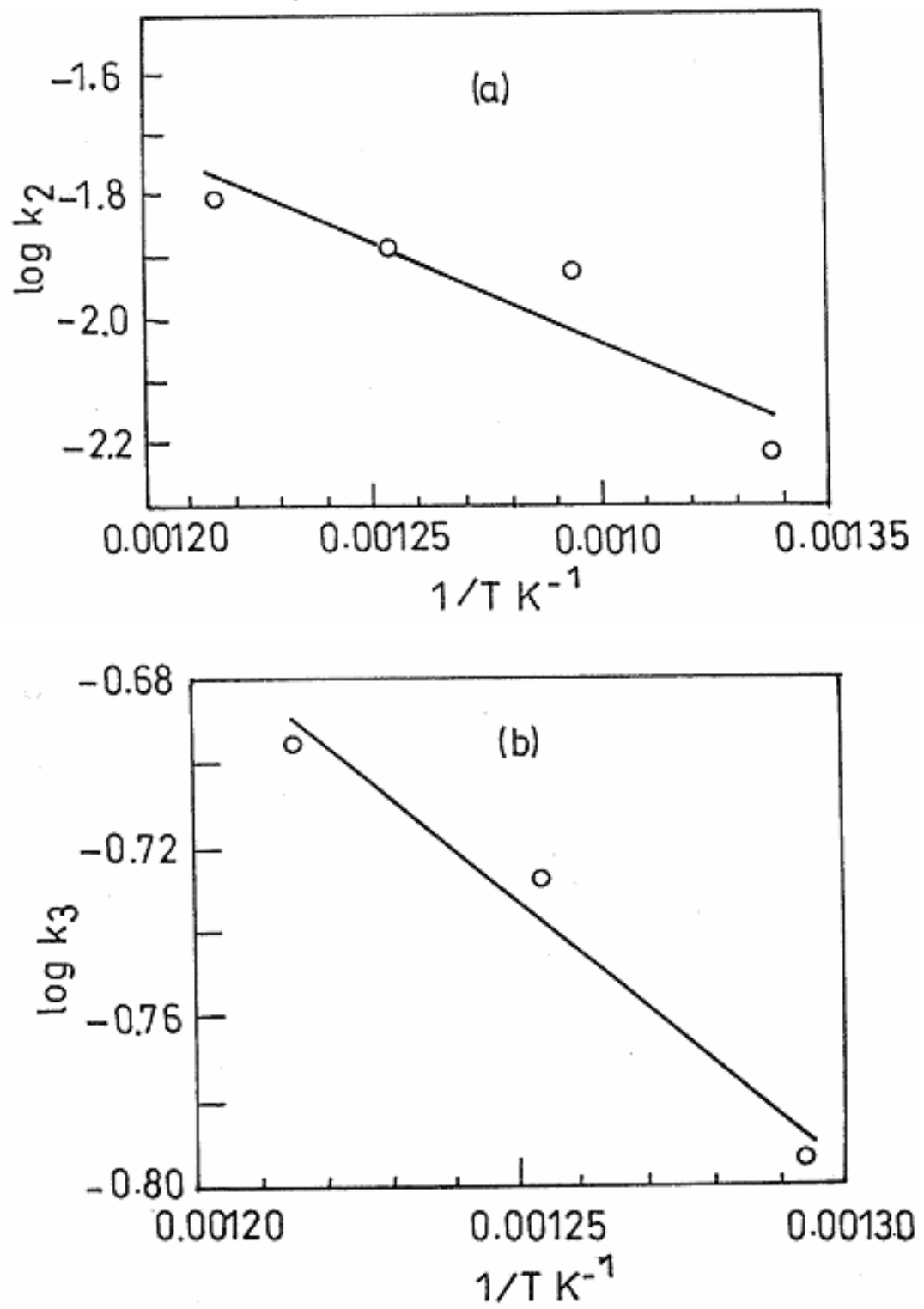

Figure 2. Variation of $\log \mathrm{K}_{2}$ (a) and $\log \mathrm{K}_{3}$ (b) with $1 / \mathrm{T}$ for iron in carbonate melt. 
The relation between $\mathrm{E}_{\text {corr }}$ and exposure time ( $\mathrm{t}$ ) can be written in the following equation [7]

$$
E_{\text {corr }}=K_{1}+k_{2} \log \left(t+t^{o}\right)
$$

where $\mathrm{K}_{1}, \mathrm{~K}_{2}$ and $\mathrm{t}^{\mathrm{o}}$ are constants. The constant $\mathrm{K}_{2}$ is taken as a measure for the rate of oxide thickening per decade of time. The relation between $\mathrm{E}_{\mathrm{corr}}$ and $\log \mathrm{t}$ is depicted in Fig. 1b. In Table 1 the values of $E_{i m m}, E_{s},\left(E_{s}-E_{i m m}\right), t_{s}, K_{2}, K_{3}$ are listed.

Table 1. Data of open circuit measurements for iron in carbonate melt at different temperatures.

\begin{tabular}{|c|c|c|c|c|c|c|c|}
\hline $\begin{array}{l}\text { Temp. } \\
{ }^{\circ} \mathrm{C}\end{array}$ & $\begin{array}{l}E_{i m m} \\
(m V)\end{array}$ & $\begin{array}{c}\mathrm{E}_{\mathrm{s}} \\
(\mathrm{mV})\end{array}$ & $\begin{array}{c}\mathrm{t}_{\mathrm{s}} \\
(\mathrm{min})\end{array}$ & $\begin{array}{c}\mathrm{E}_{\mathrm{imm}}-\mathrm{E}_{\mathrm{s}} \\
(\mathrm{mV})\end{array}$ & $\begin{array}{c}\mathrm{K}_{2} \\
\text { (mV/decade) }\end{array}$ & $\begin{array}{c}\mathrm{K}_{3} \\
\text { (mV/decade) }\end{array}$ & $\begin{array}{l}\mathrm{Fe} \% \\
\text { in melt }\end{array}$ \\
\hline 475 & -1217 & -1138 & 90.0 & 79.0 & 6.070 & 145.8 & 0.251 \\
\hline 500 & -1240 & -1127 & 140 & 113 & 11.71 & 161.1 & 0.225 \\
\hline 525 & -1249 & -1114 & 150 & 135 & 12.89 & 187.4 & 0.185 \\
\hline 550 & -1265 & -1105 & 190 & 16.0 & 15.70 & 201.8 & 0.152 \\
\hline \multicolumn{2}{|c|}{$\mathrm{E}_{\mathrm{a}}^{*}\left(\mathrm{~K}_{2}\right)$} & \multicolumn{6}{|c|}{$24 \mathrm{~kJ} / \mathrm{mol}$} \\
\hline \multicolumn{2}{|c|}{$\mathrm{E}_{\mathrm{a}}^{*}\left(\mathrm{~K}_{3}\right)$} & \multicolumn{6}{|c|}{$61.21 \mathrm{~kJ} / \mathrm{mol}$} \\
\hline
\end{tabular}

In molten carbonates the oxide ions originate by self dissociation according to the equilibrium:

$$
\mathrm{CO}_{3}^{2-} \rightleftharpoons \mathrm{CO}_{2}+\mathrm{O}^{2-}
$$

This reaction is responsible for the presence of oxide ions in the carbonate melt. In Lux -Flood, Acid -base properties, $\mathrm{CO}_{2}$ is the acid and $\mathrm{O}^{2-}$ the base.

It can be assumed that the oxide ions $\mathrm{O}^{2-}$ and carbonate ions $\mathrm{CO}_{3}{ }^{2-}$ play an important role in the oxidation process. Thus the reactions leading to the oxidation of different metals may be represented by the following equations:

$$
\mathrm{M}+\mathrm{n} / 2 \mathrm{O}^{2-} \rightleftharpoons \mathrm{MO}_{\mathrm{n} / 2}+\mathrm{ne}
$$

and/or

$$
\mathrm{M}+\mathrm{n} / 2 \mathrm{CO}_{3}{ }^{2-} \rightleftharpoons \mathrm{MO}_{\mathrm{n} / 2}+\mathrm{n} / 2 \mathrm{CO}_{2}+\mathrm{ne}
$$

According to the previously reported works $[3,7,8,12]$ the oxidation and passivation of iron may proceed as follows:

$$
\begin{gathered}
\mathrm{Fe}+\mathrm{CO}_{3}{ }^{2-} \rightarrow \mathrm{FeO}_{\mathrm{ss}}+\mathrm{CO}_{2}+2 \mathrm{e} \\
\mathrm{Fe}+2 \mathrm{CO}_{3}{ }^{2-}+\mathrm{Li}^{+} \rightarrow \mathrm{LiFeO}_{2 \mathrm{ss}}+2 \mathrm{CO}_{2}+3 \mathrm{e}
\end{gathered}
$$

A cubic solid solution (ss) of $\mathrm{FeO}$ and $\mathrm{LiFeO}_{2}$ is formed. However, $\mathrm{FeO}$ is stable only above $570{ }^{\circ} \mathrm{C}$ as: 


$$
\begin{gathered}
3 \mathrm{FeO}+\mathrm{O}^{2-} \rightleftharpoons \mathrm{Fe}_{3} \mathrm{O}_{4}+2 \mathrm{e} \\
2 \mathrm{Fe}_{3} \mathrm{O}_{4}+\mathrm{O}^{2-} \rightleftharpoons 3 \mathrm{Fe}_{2} \mathrm{O}_{3}+2 \mathrm{e}
\end{gathered}
$$

It can be assumed that in the presence of $\mathrm{Na}^{+}, \mathrm{K}^{+}, \mathrm{NaFeO}_{2}, \mathrm{KFeO}_{2}$ may also be formed.

The possible cathodic reactions in the molten carbonate may be $[3,7,8,12,15]$ :

$$
\begin{gathered}
3 \mathrm{CO}_{2}+4 \mathrm{e} \rightarrow \mathrm{C}+2 \mathrm{CO}_{3}{ }^{2-} \\
\mathrm{CO}_{3}{ }^{2-}+4 \mathrm{e} \rightarrow \mathrm{C}+3 \mathrm{O}^{2-}
\end{gathered}
$$

and/or

$$
\begin{aligned}
& 2 \mathrm{CO}_{2}+2 \mathrm{e} \rightarrow \mathrm{CO}+\mathrm{CO}_{3}^{2-} \\
& \mathrm{CO}_{3}^{2-}+2 \mathrm{e} \rightarrow \mathrm{CO}+2 \mathrm{O}^{2-}
\end{aligned}
$$

After each experiment the melt was analyzed for the determination of $w \mathrm{t} \%$ of iron dissolved in the melt. The results of analysis listed in Table 1, indicate that the value of $\left(E_{s}-E_{i m m}\right)$ increases with increasing temperature, while the amount of $\mathrm{Fe}(\mathrm{wt} \%)$ dissolved in the melt decreases. This means that the increase of melt temperature favors the formation of thicker and more protective scales on the surface of the electrode. It can be assumed that the increase of temperature enhances the process of carbonate self dissociation, leading to the formation of more oxide ions. This state helps in the formation of more thick and protective scales on the electrode surface, leading to an increase in the value of $\left(E_{s}-E_{i m m}\right)$ and a decrease in the dissolved Fe in the melt.

The Arrhenius plots of $\log \mathrm{K}_{2}$ versus $1 / \mathrm{T}$ and $\log \mathrm{K}_{3}$ versus $1 / \mathrm{T}$ are shown in Fig. $2 \mathrm{a}$ and $2 \mathrm{~b}$, respectively. From the slopes of straight lines obtained in Figs. $2 \mathrm{a}$ and $2 \mathrm{~b}$ the values of activation energy for corrosion are calculated and found to be 61.21 and $24 \mathrm{~kJ} / \mathrm{mol}$. The former value of the activation energy indicates that the corrosion process is activation controlled, while the latter value indicates that the process of thickening of oxide scales is diffusion-controlled, occurring at the oxide matrix.

Fig. 3 represents the galvanostatic anodic polarization behaviour of iron electrode immersed in carbonate melt at temperatures of $475,500,525$ and $550{ }^{\circ} \mathrm{C}$. The polarization curves exhibit Tafel's passivity, and passivity breakdown regions. At the passivity breakdown the potential suddenly shifts towards the active direction, indicating the destruction of the passive oxide scales. After the end of each experiment the carbonate melt was found to be contaminated by black and brown scales. The analysis of the melt showed that the amount of iron in the melt was considerably higher than that found in the melt under open circuit measurements. 


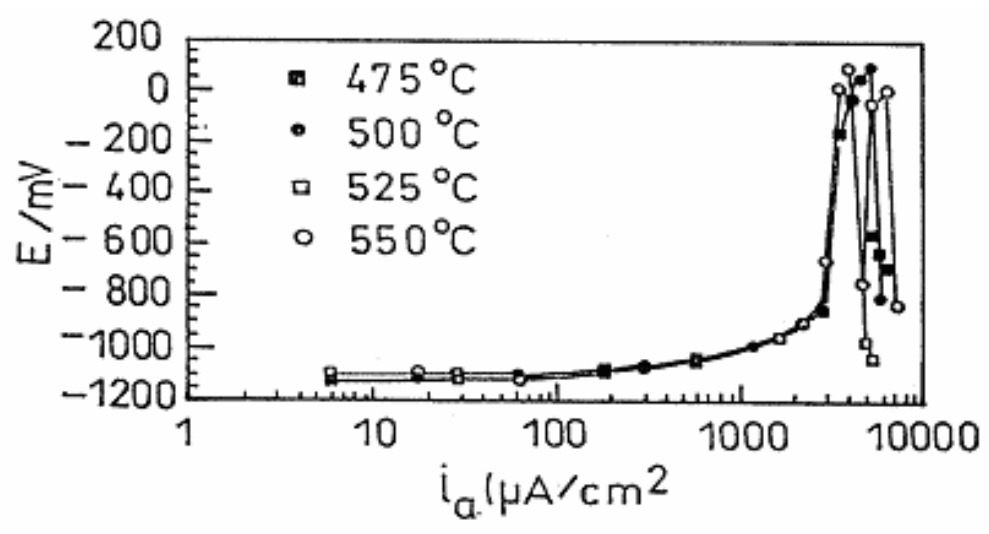

Figure 3. Galvanostatic anodic polarization curves for iron in carbonate melt at different temperatures.
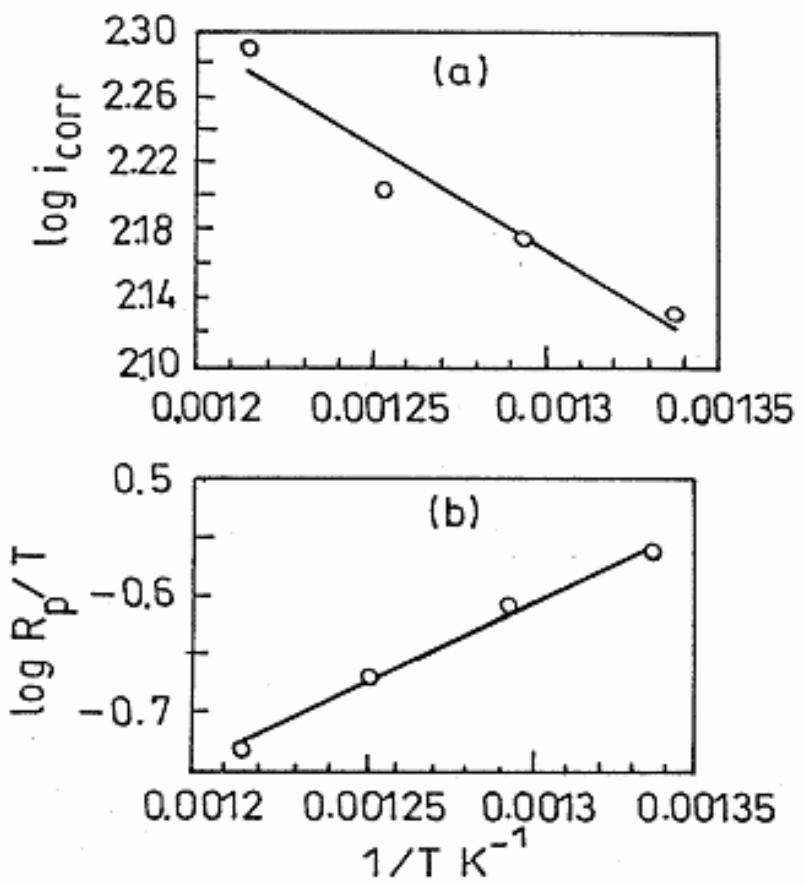

Figure 4. Arrhenius plots of $\log i_{\text {corr }}(a)$ and $\log \left(R_{p} / T\right)(b)$ versus $1 / T$ for iron in carbonate melt.

Table 2. Data of galvanoststic anodic polarization measurements for iron in carbonate melt at different temperatures.

\begin{tabular}{|c|c|c|c|c|c|c|}
\hline Temp. ${ }^{\circ} \mathrm{C}$ & $\begin{array}{c}\text { Passivity range } \\
(\mathrm{mV})\end{array}$ & $\begin{array}{c}\mathrm{R}_{\mathrm{p}} \\
(\Omega)\end{array}$ & $\begin{array}{c}\mathrm{i}_{\mathrm{o}} \\
\left(\mu \mathrm{A} / \mathrm{cm}^{2}\right)\end{array}$ & $\begin{array}{c}\mathrm{i}_{\text {corr }} \\
\left(\mu \mathrm{A} / \mathrm{cm}^{2}\right)\end{array}$ & $\begin{array}{c}\mathrm{i}_{\mathrm{p}} \\
\left(\mu \mathrm{A} / \mathrm{cm}^{2}\right)\end{array}$ & $\begin{array}{c}\mathrm{Fe} \% \\
\text { in melt }\end{array}$ \\
\hline 475 & 1106 & 204 & 105.1 & 135 & 3900 & 0.502 \\
\hline 500 & 1229 & 190 & 116.4 & 150 & 4100 & 0.421 \\
\hline 525 & 1109 & 170 & 134.6 & 160 & 4500 & 0.403 \\
\hline 550 & 1127 & 152 & 155.2 & 195 & 5000 & 0.384 \\
\hline $\mathrm{E}_{\mathrm{i} \text { corr }}^{*}$ & \multicolumn{5}{|c|}{$23.9 \mathrm{~kJ} / \mathrm{mol}$} \\
\hline $\mathrm{E}_{\mathrm{Rp}}$ & \multicolumn{5}{|c|}{$26.9 \mathrm{~kJ} / \mathrm{mol}$} \\
\hline
\end{tabular}


The passivity potential range are deduced from the polarization curves of Fig. 3 at different temperatures and listed in Table 2. The values of the passivity potential range ranged from 1106 to $1229 \mathrm{mV}$. From these values and those previously reported for iron-rich-nickel alloys [3] it can be assumed that under open circuit conditions and low polarization, $\mathrm{LiFeO}_{2}, \mathrm{Fe}_{3} \mathrm{O}_{4}$ and $\mathrm{Fe}_{2} \mathrm{O}_{3}$ can be formed on the surface of iron electrode. At higher anodic polarization the formation of $\mathrm{LiFe}_{5} \mathrm{O}_{8}$ can occur by the reaction:

$$
\mathrm{LiFeO}_{2}+4 \mathrm{Fe}+6 \mathrm{CO}_{3}{ }^{2-} \rightarrow \mathrm{LiFe}_{5} \mathrm{O}_{8}+6 \mathrm{CO}_{2}+12 \mathrm{e}
$$

At higher anodic potential $\alpha-\mathrm{Fe}_{2} \mathrm{O}_{3}$ may be formed according to the reaction:

$$
2 \mathrm{Fe}+3 \mathrm{O}^{2-} \rightarrow \mathrm{Fe}_{2} \mathrm{O}_{3}+6 \mathrm{e}
$$

The passivity breakdown may be attributed to the reaction:

$$
\mathrm{CO}_{3}{ }^{2-} \rightarrow \mathrm{CO}_{2}+1 / 2 \mathrm{O}_{2}+2 \mathrm{e}
$$

which is the anodic decomposition of oxygen carbonates, and carbon dioxide is formed and evolves as gas.

It can be assumed that the iron scales formed latter at high anodic polarization are non-adherent to the electrode's surface. The anodic decomposition of $\mathrm{CO}_{3}{ }^{2-}$ with evolution of $\mathrm{CO}_{2}$ and $\mathrm{O}_{2}$ gases may cause the palliation of these scales in the melt.

The values of polarization resistance, $\mathrm{R}_{\mathrm{p}}$ are calculated from $\mathrm{E}$ versus i plots for iron electrodes under low polarization conditions, at different temperature, where $\left(R_{p}=\Delta E / \Delta i\right)$. The values of exchange current density, $i_{o}$, are calculated using the well known equation:

$$
(\mathrm{dE} / \mathrm{di})_{\eta=0}=\mathrm{R}_{\mathrm{p}}=\left(\frac{R T}{Z F}\right) \cdot\left(\frac{1}{i_{o}}\right)
$$

where $R_{p}$ is the polarization resistance of the oxide scale at low polarization conditions, $\mathrm{R}$ is the gas constant, $\mathrm{T}$ is the absolute temperature, $\mathrm{Z}$ is the number of the electrons $(Z$ is taken roughly $=3$ ), and $F$ is the Faradays constant. The values of corrosion current density, $i_{\text {corr }}$, were deduced from the polarization curves by extrapolating the linear portions of the anodic Tafel's line to zero over voltage $(\eta=0)$, where $\eta$ equals the difference between the polarization potential and open circuit potential. The passivation current density, $\mathrm{i}_{\mathrm{p}}$, represents the current density at which the onset of passivity occurs. The different values of these parameters are listed in Table 2. These data indicate that the increase of temperature increases the values of $i_{0}, i_{\text {corr }}$ and $i_{p}$, while $R_{p}$ decreases.

The Arrhenius plots of $\log i_{\text {corr }}$ and $\log \left(\mathrm{R}_{\mathrm{p}} / \mathrm{T}\right)$ versus $(1 / \mathrm{T})$ are shown in Fig. $4 \mathrm{a}$ and $4 b$, respectively. From the slopes of the straight lines of Figs. $4 a$ and $4 b$, the values of activation energy of corrosion are calculated for iron, using equations:

$$
\mathrm{d} \log \mathrm{i}_{\mathrm{corr}} / \mathrm{d}(1 / \mathrm{T})=\Delta \mathrm{E}_{\text {corr }}^{*} / 2.303 \mathrm{R}
$$




$$
\log \left(\mathrm{R}_{\mathrm{p}} / \mathrm{T}\right)=\text { constant }+\frac{\Delta E_{\text {corr }}^{*}}{2.303 R T}
$$

The calculated values of $\Delta \mathrm{E}^{*}$ corr are found to be 26.9 and $23.9 \mathrm{~kJ} / \mathrm{mol}$, respectively. The two values of activation energy of corrosion are near to each other and indicate that the process is diffusion controlled.

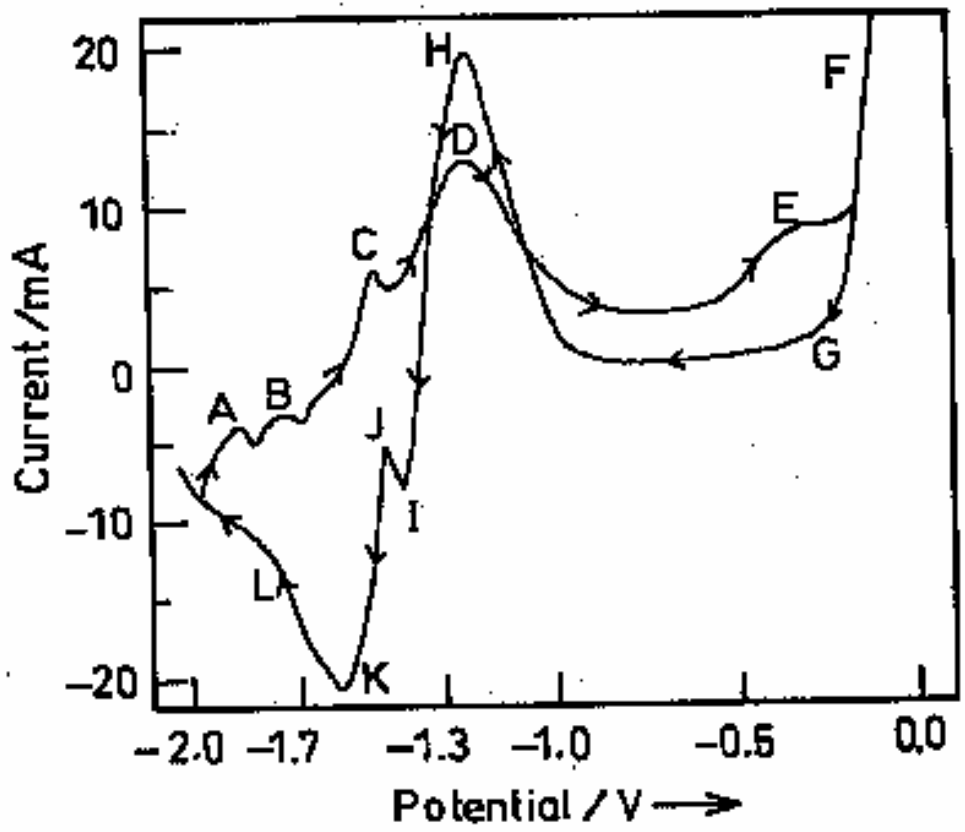

Figure 5. Cyclic voltammograms of iron in carbonate melt at $500{ }^{\circ} \mathrm{C}$, scan rate 25 $\mathrm{mV} / \mathrm{s}$.

Cyclic voltammetric measurements were carried out on iron in carbonate melt at $500{ }^{\circ} \mathrm{C}$. The complete cyclic voltammogrames of iron were recorded after immersion, the potential was set at $-2000 \mathrm{mV}$ and the scan was started immediately. The anodic potential limit was $0 \mathrm{mV}$. Fig. 5 represents the cyclic voltammogram of iron immersed in carbonate melt at temperature of $500{ }^{\circ} \mathrm{C}$ and with a scan rate of $25 \mathrm{mV} / \mathrm{s}$. In this voltammogram a number of peaks and shoulders can observed during the anodic and cathodic scans. In the oxidation and reduction reaction are assigned to the peaks and shoulders donated with capitals on the cyclic voltammograme for Fe, Fig. 5.

At immersion and measurements starting, the current greatly increases reaching peak A $(\approx-1900$ to $-1800 \mathrm{mV})$. This peak may be attributed to the reduction of $\mathrm{CO}_{3}{ }^{2-}$ according to the reaction:

$$
\mathrm{CO}_{3}^{2-}+4 \mathrm{e} \rightarrow \mathrm{C}+3 \mathrm{O}^{2-}
$$

Peak B (-1700mv) may be ascribed to the oxidation of precipitated carbon, at even more cathodic potentials:

$$
\mathrm{C}+3 \mathrm{O}^{2-} \rightarrow \mathrm{CO}_{3}{ }^{2-}+4 \mathrm{e}
$$


The current increase that starts between $(-1650-1500 \mathrm{mV})$ results in peak $\mathrm{C}$. This peak is mainly due to the oxidation of metallic iron to $\mathrm{FeO}$ and $\mathrm{LiFeO}_{2}$ to form a cubic solid solution. The formation of this cubic solid solution may stabilize $\mathrm{FeO}$ at these low temperatures $\left(500{ }^{\circ} \mathrm{C}\right)$. Also $\mathrm{FeO}$ may decompose to $\mathrm{Fe}_{3} \mathrm{O}_{4}$ and apparently to $\mathrm{Fe}_{2} \mathrm{O}_{3}$.

The current increase at $(-1400 \mathrm{mV})$ ends in a wide peak $\mathrm{D}$ (the start and end of this peak cover the potential range -1400 to $-900 \mathrm{mV}$ ). This peak is ascribed by the oxidation of iron to $\alpha-\mathrm{LiFeO}_{2}$ and $\alpha-\mathrm{LiFe}_{5} \mathrm{O}_{8}$ according to equations $(6,13)$. This is in agreement with thermodynamic calculations [11]. These calculations show that $\alpha-\mathrm{LiFe}_{5} \mathrm{O}_{8}$ is formed at more anodic potentials than $\alpha-\mathrm{LiFeO}_{2}$. The valency of iron ions in the oxide scale does not change, but due to a change of the lattice, the formation of $\alpha-\mathrm{LiFe}_{5} \mathrm{O}_{8}$ takes place at more anodic potentials.

The current increase that starts between $(-600$ to $-350 \mathrm{mV})$ results in shoulder or peak E. This peak/shoulder may be due mainly to the formation of $\alpha-\mathrm{LiFe}_{2} \mathrm{O}_{3}$ according to the equation (14).

From the phase diagram of Yokokawa et al. [11] it appears that $\alpha-\mathrm{Fe}_{2} \mathrm{O}_{3}$ can be stable at more anodic potentials. The oxidation state of iron does not change any more, but relative positions of oxygen and iron in the lattice change considerably. As a consequence of different formation energy, $\alpha-\mathrm{Fe}_{2} \mathrm{O}_{3}$ is formed at more anodic potentials.

The current increase $\mathrm{F}(-200$ to $-100 \mathrm{mV})$ observed on the cyclic voltammograms of iron, may be ascribed to the anodic decomposition of carbonate, according to eq. 15. Oxygen and carbon dioxide are formed and evolve as gases.

During the cathodic scan in the cyclic voltammogram given in Fig. 5, several peaks and shoulders are marked with capitals.

Region $\mathrm{G}$ is most likely to represent the reduction of the oxygen and carbon dioxide dissolved in the melt (produced by anodic decomposition of $\mathrm{CO}_{3}{ }^{2-}$ ).

$$
\mathrm{CO}_{2}+1 / 2 \mathrm{O}_{2}+2 \mathrm{e} \rightarrow \mathrm{CO}_{3}^{2-}
$$

The current increase in the region $\mathrm{H}$, i.e., the current becomes more anodic during the cathodic scan. This may be due to cracking or spoliation of the scale as a sequence of reduction reaction, so that new material can oxidize, e.g., to form $\alpha-\mathrm{LiFe}_{5} \mathrm{O}_{8}$ and cause an anodic current. Alternatively, the ionic conductivity of the scale may change as a function of the potential, so that ions can diffuse through the oxide scale and oxidation can take place. In this region the following reduction reactions may occur:

$$
\begin{gathered}
\mathrm{LiFe}_{5} \mathrm{O}_{8}+4 \mathrm{e} \rightarrow \mathrm{LiFeO}_{2}+4 \mathrm{FeO}+2 \mathrm{O}^{2-}{ }_{\text {sol }} \\
\mathrm{LiFeO}_{\mathrm{ss}}+\mathrm{e} \rightarrow \mathrm{FeO}_{\mathrm{ss}}+\mathrm{Li}++\mathrm{O}^{2-}{ }_{\text {sol }}
\end{gathered}
$$

These reactions cause great decreases in the current to I. The formed $\mathrm{FeO}$ is unstable at this temperature and may oxidize to $\mathrm{Fe}_{3} \mathrm{O}_{4}$, causing the appearance of peak J. After this peak the current greatly decreases reaching peak $\mathrm{K}$ and then increases (L). These changes occur in a wide region of potential from -1450 to $1950 \mathrm{mV}$. In this region the following reduction reactions may occur: 


$$
\mathrm{LiFeO}_{2}+3 \mathrm{e} \rightarrow \mathrm{Fe}+\mathrm{Li}^{+}+2 \mathrm{O}^{2-} \text { sol }
$$

accompanied by reduction of any $\mathrm{FeO}_{\mathrm{ss}}$

$$
\mathrm{Fe} \mathrm{O}_{\mathrm{ss}}+2 \mathrm{e} \rightarrow \mathrm{Fe}+\mathrm{O}^{2-}{ }_{\text {sol }}
$$

Also, the reduction of dissolved iron ions may occur in this potential region, where the metal ions dissolved in the melt diffuse to the metal, and are reduced to the metallic state. These reactions proceed at the current increase L, which also reflects the carbonate decomposition by the reaction (19).
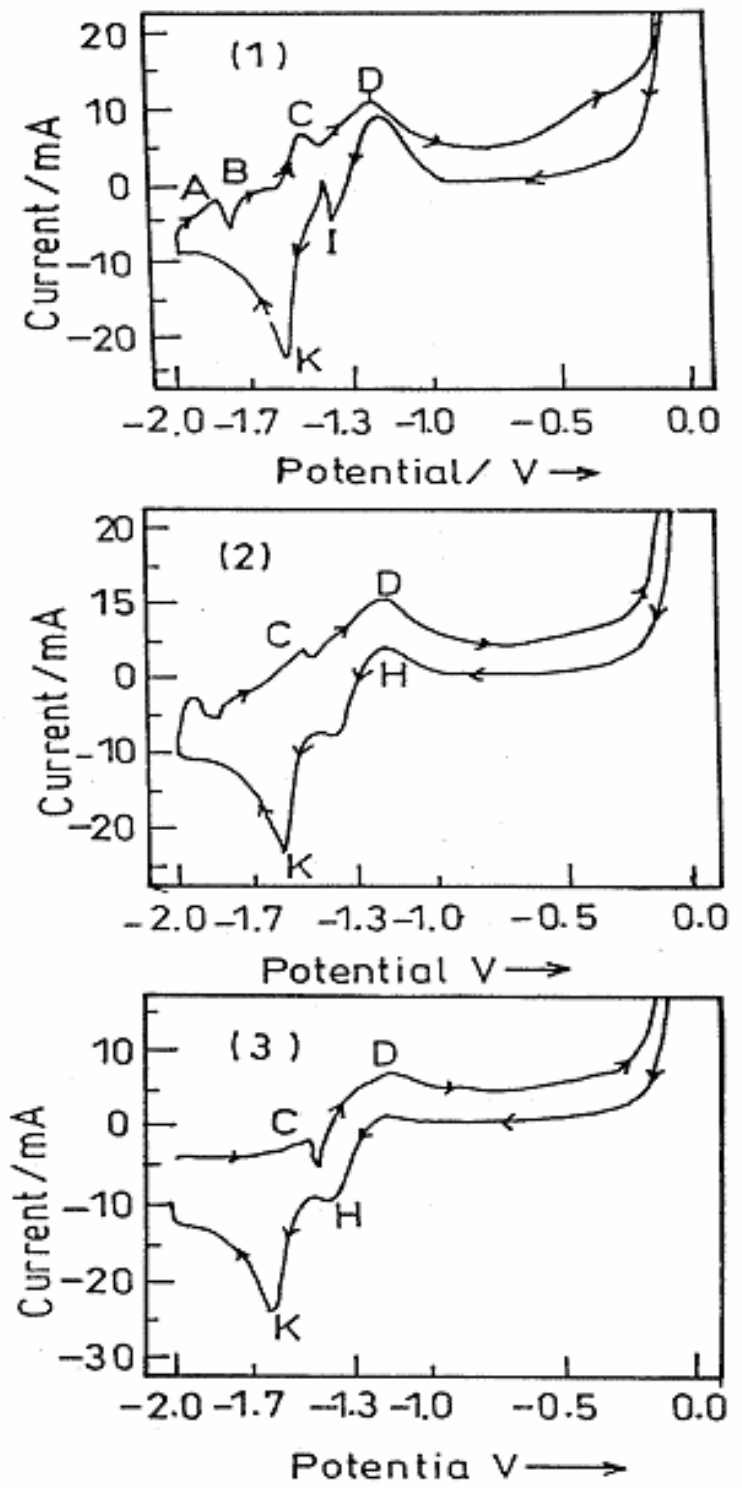

Figure 6. Cyclic voltammograms of iron in carbonate melt at $500{ }^{\circ} \mathrm{C}$ at different scan rates (1) $50 \mathrm{mV} / \mathrm{s}$, (2) $75 \mathrm{mV} / \mathrm{s}$, (3) $100 \mathrm{mV} / \mathrm{s}$.

Fig. 6 represents, respectively, the cyclic voltammograms for iron in the carbonate melt at $500{ }^{\circ} \mathrm{C}$ at different scan rates 20,75 and $100 \mathrm{mV} / \mathrm{s}$. The voltammograms of Figs. 5 and 6 reveal that, the increase of scan rate lowers the 
height of many peaks, such as peak D (anodic scan) and peak $\mathrm{H}$ (cathodic scan). These peaks tend to be flat at scan rate of $100 \mathrm{mV} / \mathrm{s}$. Also, shoulder E (anodic scan) tends to disappear with the increase of the scan rate. On the other hand the peak current of peak K (cathodic scan) increases with increase of scan rate. These results indicate that iron tends to be more passive with the increase of scan rate. The process of formation of $\alpha-\mathrm{Fe}_{2} \mathrm{O}_{3}$ (at shoulder $\mathrm{E}$ ) on the electrode surface is slow; for this reason, this shoulder tends to disappear at high scan rates. The process of spoliations and/or cracking of oxide scales (peak $\mathrm{H}$ on the cathodic scan) greatly decreases with the increases of scan rate. This process may be related to the possibility of $\alpha-\mathrm{Fe}_{2} \mathrm{O}_{3}$ at the last stages of anodic scan (shoulder $\mathrm{E}$ ). Figs. 7 and 8 represent the potential vs. time curves for the iron electrodes immersed in $0.05 \mathrm{M} \mathrm{HCl}$, after their oxidation in carbonate melt at 500 and 550 ${ }^{\circ} \mathrm{C}$ under open circuit conditions and galvanostatic anodic polarization conditions respectively.

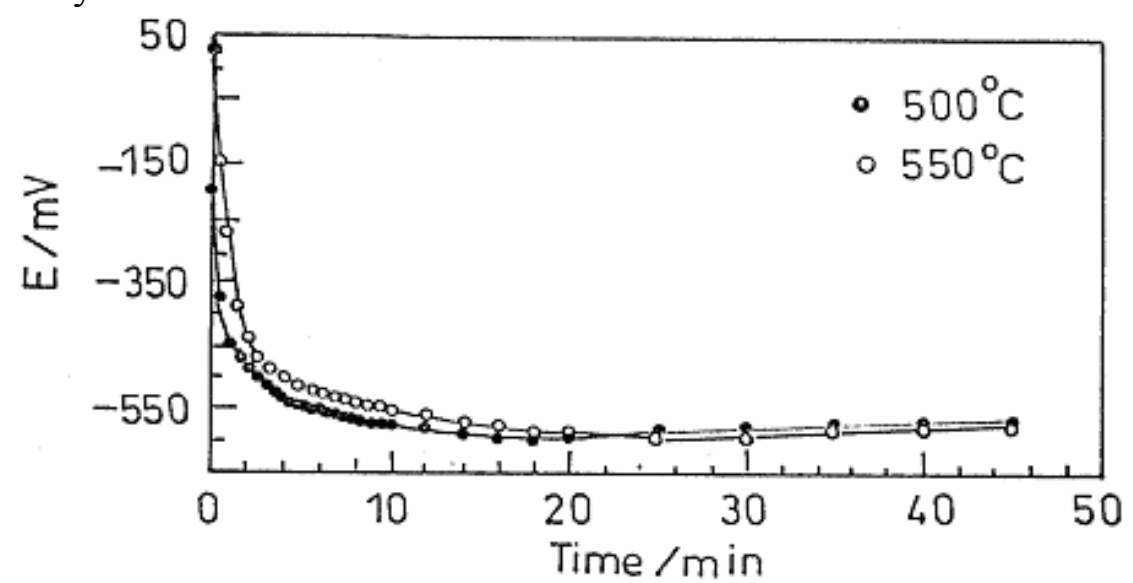

Figure 7. Potential-time curves for iron in $0.05 \mathrm{M} \mathrm{HCl}$ after oxidation in carbonate melt under open circuit conditions.

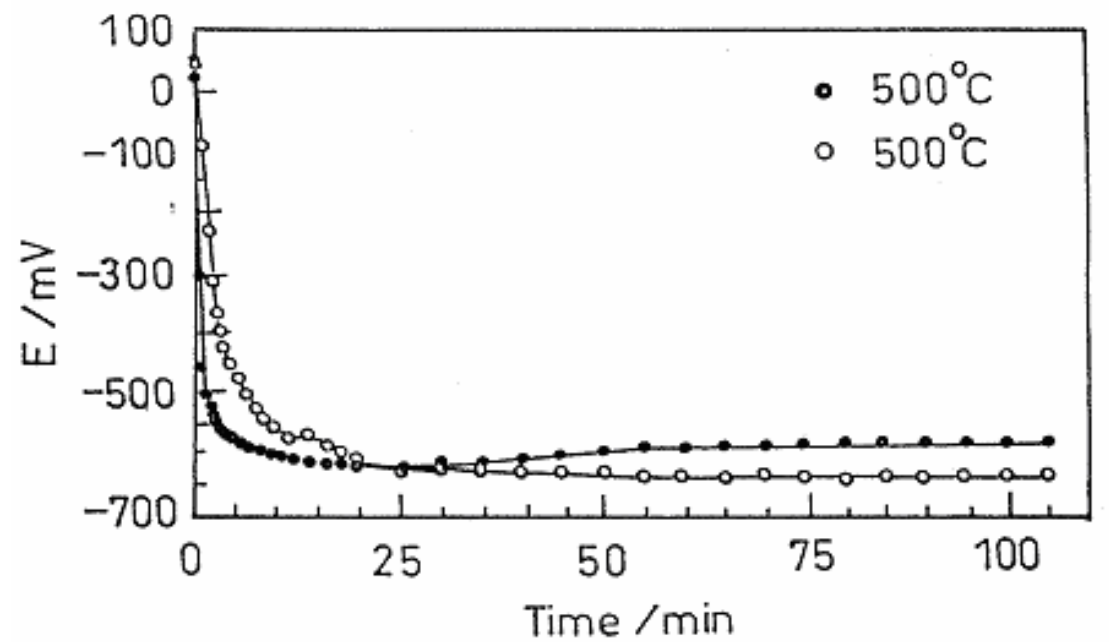

Figure 8. Potential-time curves for iron in $0.05 \mathrm{M} \mathrm{HCl}$ after oxidation in carbonate melt under galvanostatic anodic polarization conditions. 
At immersion of the preoxidized electrodes in $0.05 \mathrm{M} \mathrm{HCl}$, the corrosion potential greatly shifts to active direction with elapse of time slowly till attaining its steady state. The values of $E_{i m m}, E_{s},\left[E_{i m m}-E s\right]$, time of corrosion, $t_{s}$, and corrosion rate are deduced from the curves of Figs. $(7,8)$ and listed in Table 3.

If we roughly consider the immersion potential, $\mathrm{E}_{\mathrm{imm}}$, as starting potential of the preoxidised electrode and the steady state potential, $E_{\mathrm{s}}$, as the end potential, the value of dissolution potential range, $\left(E_{i m m}-E_{s}\right)$ can be calculated. The time required for the shift of the potential from $E_{i m m}$ to $E_{s}$ (time of dissolution) was reached, $t_{s}$. The rate of dissolution of oxide scales can be roughly calculated by dividing the values of $\left(E_{i m m}-E_{s}\right)$ by $t_{s}$. The obtained values of these calculations are listed in Table 3. The value of rate of scale dissolution is expressed as $\mathrm{mV}$ $\mathrm{min}^{-1}$. This value is directly proportional to the decrease in the scale thickness with time $[14,15]$. The mode of the decrease of potential with time, plots of Fig. 7 and 8 , indicates the presence of multilayered scale on the iron surface. The outer layer is less protective than the inner one.

Table 3. Data of corrosion tests on the oxide scales of iron in $0.05 \mathrm{M} \mathrm{HCl}$.

\begin{tabular}{|c|c|c|c|c|c|c|}
\hline $\begin{array}{c}\text { Oxidation } \\
\text { condition }\end{array}$ & Temp. $^{\mathbf{0}} \mathbf{C}$ & $\begin{array}{c}\mathbf{E}_{\mathbf{i m m}} \\
(\mathbf{m V})\end{array}$ & $\begin{array}{c}\mathbf{E}_{\mathbf{s}} \\
(\mathbf{m V})\end{array}$ & $\begin{array}{c}\mathbf{E}_{\mathbf{i m m}}-\mathbf{E}_{\mathbf{s}} \\
(\mathbf{m V})\end{array}$ & $\begin{array}{c}\mathbf{t}_{\mathbf{s}} \\
(\mathbf{m i n})\end{array}$ & $\begin{array}{c}\text { Rate } \\
(\mathbf{m V} / \mathbf{m i n})\end{array}$ \\
\hline \multirow{2}{*}{ Open circuit } & 500 & -200 & -568 & 368 & 35 & 10.51 \\
& 550 & 32 & -575 & 607 & 40 & 15.18 \\
\hline Polarization & 500 & 30 & -590 & 620 & 65 & 9.540 \\
& 550 & 63 & -639 & 702 & 85 & 8.260 \\
\hline
\end{tabular}

\section{Conclusions}

1- The iron undergoes spontaneous passivation in molten carbonate and oxide scale formation occurs as a result of the electrochemical reactions taking place between iron and carbonate melts.

2- Iron has high susceptibility to corrosion in carbonate melt under high anodic potentials and the spoliation of oxide scales occurs at these high potentials.

3- The cathodic and anodic decomposition of carbonate occurs at more negative and more positive potentials, respectively. For this reason the potential range of cyclic voltammograms is limited by these decomposition reactions of carbonate.

4- The oxide scales formed on iron surface are multilayered, where the outer layer is less protective than the inner one.

\section{References}

1. J.P.T. Vossen, L. Plomp, J.H.W. de Wit, J. Electrochem. Soc. 141 (1994) 340.

2. J.P.T. Vossen, L. Plomp, J.H.W. de Wit, C. Rietveld, J. Electrochem. Soc. 142 (1995) 3327.

3. J.P.T. Vossen, A.H.H. Jonssen, J.H.W. de Wit, J. Electrochem. Soc. 143 (1996) 58. 
4. J.P.T. Vossen, P.C.H. Ament, J.H.W. de Wit, J. Electrochem. Soc. 143 (1996) 2272.

5. C.G. Lee, H. Nakano, J. Nishina, I. Uchida, S. Kuroe, J. Electrochem. Soc. 145 (1998) 2747.

6. N. Tatsuo, Y. Kohichi, U. Isamu, Proc. Electrochem. Soc. (1993) 93, Proceedings of the Third International Symposium on Carbonate Fuel Cell Technology, 1993, p. 264.

7. S.A. Salih, A.N. El-Masri, A.M. Baraka, J. Mater. Sci. 36 (2001) 1.

8. A.A. Attia, S.A. Salih, A.M. Baraka, Electrochem. Acta 48 (2002) 113.

9. R.B. Swaroop, J.W. Sim, K. Kinoshila, J. Electrochem. Soc. 125 (1978) 1799.

10. R.A. Dando, L.G. Marianowski, H.C. Maru, J.R. Selnan, J. Electrochem. Soc. 131 (1984) 2535, 2541.

11. H. Yokokawa, N. Sakai, T. Kawada, M. Dokiya, J. Electrochem. Soc. 140 (1993) 2565.

12. J.P.T. Vossen, R.C. Makkus, J.H.W. de Wit, J. Electrochem. Soc. 143 (1996) 66.

13. H.A. Abd-El-Rahman, A. Baraka, S.A. Abd-El-Gawad, J. Appl. Electrochem. 29 (1999) 1205.

14. W.M. Carrol, C.B. Berslin, Br. Corros. J. 26 (1991) 225.

15. W.A. Badawy, F.M. Alkharafi, E.Y. Al-Hassan, Corros. Prevention \& Control 46 (1999) 51. 